\title{
Analysing the Effect of Financial Risk Perception, Risk Tolerance on Investment Behaviour: An Empirical Analysis
}

\author{
M Ramu $^{a^{*}}$, Dr CH Hymavathi ${ }^{\text {b }}$, Mr. A SaiManideep ${ }^{c}$ \\ a,c Assistant Professor, Department of Management Studies, Vignan's Foundation for Science, Technology \& Research \\ University, Guntur, Andhra Pradesh, India \\ ${ }^{\mathrm{b}}$ Associate Professor, Department of Management Studies, Vignan's Foundation for Science, Technology \& Research \\ University, Guntur, Andhra Pradesh, India
}

Article History: Received: 10 November 2020; Revised 12 January 2021 Accepted: 27 January 2021; Published online: 5 April 2021

\begin{abstract}
Investment decision making is a complex process that depends on several factors that vary from one individual to another. Regardless of the type of decision that is made in life, people behave differently. To distinguish between risk tolerance and risk perception, we must first define risk. Risk is, of course, uncertainty about the result. Any decision that casts doubt on at least one of the possible outcomes is risky. Perception is the assessment of a level of risk which usually involves an understanding of the situation, that is, there is an explanation for objective reality. Risk tolerance is the level at which an individual is willing to accept the risks associated with investments. This paper determines the relation between risk perception, risk tolerance and investment behaviour using inferential statistical analysis and draws the conclusions from the obtained results.
\end{abstract}

Keywords: Risk perception, risk tolerance, investment behaviour, factor analysis, regression analysis

\section{Introduction}

Investment decision making is a complex process that depends on several factors that vary from one individual to another. Regardless of the type of decision that is made in life, people behave differently. Some make decisions based on judgment, while others consider many other factors that lead to action on those appropriate decisions. Decision-making becomes easier when investors are well aware of all the confusing variables. Variables that guide them to make the right decision to avoid or minimize future losses (Awais et al., 2016).

During the investment decision making period, investors face very critical factors such as risk, ambiguity and option overload. This is a challenge for financial professionals, advanced investors and especially ordinary private households. Investors must take risk in their financial decisions (Awais et al., 2016; Hoffmann et al., 2015).

Investors' understanding of the risk and reward characteristics of a particular security or stock market is generally seen as the main drivers of their decision-making. (Hoffmann et al., 2015; Trujillo-Barrera et al., 2016). Financial risk tolerance is defined as a comfort level that an individual is willing to accept while putting their current wealth at risk for future growth. The fundamental duty of care when advising individual clients is that financial advisers must be aware of the attitudes and needs of their clients, including their investment objectives, investment experience, and desired financial risk tolerance levels. (Gibson et al., 2013; Nobre \& Grable, 2015).

What is less known, however, is whether changes in these perceptions, such as individual investors' return expectations (i.e., investors' optimism about their portfolios' returns), risk tolerance (i.e., investors' general attitude (like or dislike) toward financial risk), and risk perceptions (i.e., investors' interpretations of the riskiness of the stock market) are also capable of explaining actual trading and risk-taking decisions. This is not true because investors manage alternative options and risks differently than actual options and risks, and actual decision-making is much more complicated than alternative decision making in a laboratory setting. (Hoffmann et al., 2015). Thus, based on the theme of the current study the following research questions are evaluated.

\section{Research Questions:}

1. Do risk perception significantly, effects the risk tolerance?

2. Do risk tolerance significantly effects investment behaviour?

3. Do risk perception significantly effects investment behaviour? 


\section{Review of Literature:}

Risk:

To distinguish between risk tolerance and risk perception, we must first define risk. Risk is, of course, uncertainty about the result. Any decision that casts doubt on at least one of the possible outcomes is risky. The inherent risk in any situation depends on the range of possible outcomes and the probability and value of any particular outcome. Therefore, in the financial context, risk tolerance is the level of risk that an individual chooses when making a financial decision. If one person is willing to bet $\$ 50$ on a coin draw, that amount will be lost or doubled, and if another person is unwilling to make the same bet, we can assume that the first person is risky tolerance for one another (Roszkowski \& Davey, 2010). The concept of risk is sometimes differentiated from the concept of "uncertainty" or "ambiguity," the difference being that under "risk" the probabilities are known, whereas in the case of uncertainty/ambiguity, the probabilities associated with the various outcomes are unknown (Roszkowski \& Davey, 2010).

\section{Financial Risk Perception and Investment Behaviour:}

Perception is the assessment of a level of risk which usually involves an understanding of the situation, that is, there is an explanation for objective reality. Research shows that risk perception is the work of innate risk perceptions rather than technical measures of risk such as beta, standard deviation or differentiation. (Roszkowski \& Davey, 2010; Trujillo-Barrera et al., 2016). One aspect of the mental process through the senses, such as perception, sight, hearing and feeling, is influenced by information, so these senses influence judgment. Anyone who receives information can use it to develop a picture of the results of that information (Aeknarajindawat, 2018).

Risk perception plays an important role in human behavior, especially with regard to decision-making in situations of uncertainty. If some people experience a loss due to a bad decision made, it is called a dangerous situation, especially if the loss affects their financial situation. Therefore, risk perception is a judgment of a risk state that largely depends on the characteristics and psychological state of the individual. (Aeknarajindawat, 2018; Weber \& Milliman, 1997)

\section{Financial Risk Tolerance and Investment Behaviour:}

Risk tolerance is the level at which an individual is willing to accept the risks associated with investments. It also means how an individual responds and acts in relation to the risks of investment. Investors may like risk, avoid it or ignore it. (Aeknarajindawat, 2018). Let's start by looking at the term most commonly used by financial advisers when it comes to assuming clients' tolerance for risk. Whenever a consultant tells his client that he is less tolerant, the consultant means that the client is more or less willing to adopt abusive behavior. As we will see below, the most important task a financial advisor faces when examining the risk profile is to accurately measure financial risk tolerance (Gibson et al., 2013; Nobre \& Grable, 2015).

\section{Research Framework:}

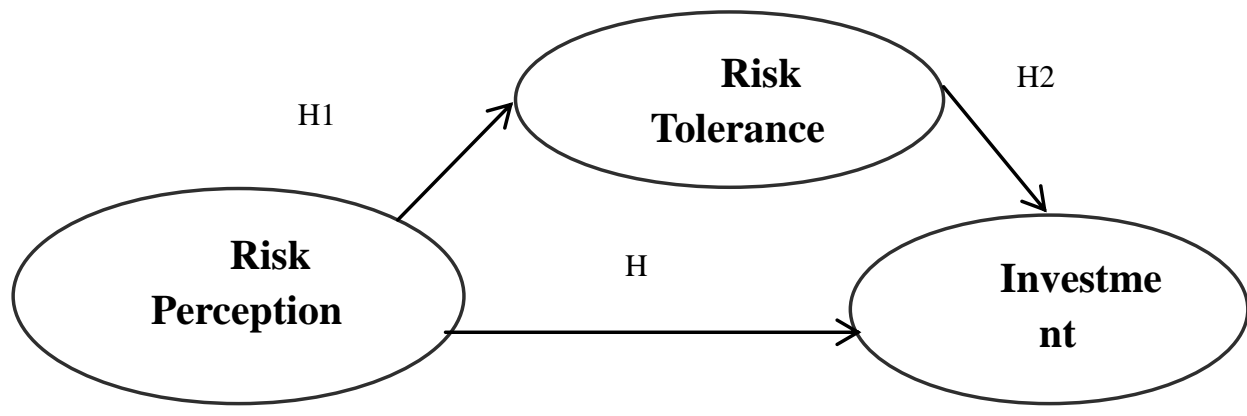

Figure 1: Proposed Research Model

\section{Hypotheses construction:}

H1: Risk perception significantly effects the risk tolerance of the investor.

$\mathrm{H} 2$ : Risk tolerance significantly effects the investment behaviour of the invertor.

H3: Risk perception significantly effects the investment behaviour of the investor. 


\section{Methodology:}

The questionnaire consists of nine questions and all the questions were made in relevance to likert scale which is very famous in capturing intention and behavioural studies. The items in the scale are validated using explorative factor analysis. The scale under the construct risk perception is as follows: "The investment I choose is definitely right and will perform well", "The investment that I choose has good performance and convincing results", "The investment that I choose as a significant value increase in the future", "The investment that I choose has a good rate of return". The scale items under risk tolerance are: "I plan on the money I am investing", "My most important investment goal is raise some growth and make income", "I expect my future income to increase". The items under the construct Investment behaviour: "I tend to invest as per my convenience", "I tend to invest hence I am financially secure". The measurement on the scale is 5 point Likert scale ( $1=$ strongly agree to $5=$ strongly disagree).

\begin{tabular}{|c|c|c|}
\hline Study Construct & Questionnaire & Empirical Support \\
\hline Risk Perception & $\begin{array}{l}\text { 1. The investment I choose is definitely right and will } \\
\text { perform well (RP1) } \\
\text { 2. The investment that I choose has good performance } \\
\text { and convincing results (RP2) } \\
\text { 3. The investment that I choose as a significant value } \\
\text { increase in the future (RP3) } \\
\text { 4. The investment that I choose has a good rate of } \\
\text { return (RP4) }\end{array}$ & $\begin{array}{l}\text { (Aeknarajindawat, } 2018 \text {; } \\
\text { Nobre \& Grable, 2015; Weber } \\
\text { et al., 2005; Weber \& } \\
\text { Milliman, 1997) }\end{array}$ \\
\hline Risk Tolerance & $\begin{array}{l}\text { 5. I plan on the money I am investing (RT1) } \\
\text { 6. My most important investment goal is raise some } \\
\text { growth and make income (RT2) } \\
\text { 7. I expect my future income to increase (RT3) }\end{array}$ & $\begin{array}{l}\text { (Awais et al., 2016; Gibson et } \\
\text { al., 2013; Roszkowski \& } \\
\text { Davey, 2010; Zhou \& Dai, } \\
\text { 2019) }\end{array}$ \\
\hline $\begin{array}{l}\text { Investment } \\
\text { Behaviour }\end{array}$ & $\begin{array}{l}\text { 8. I tend to invest as per my convenience (BI1) } \\
\text { 9. I tend to invest hence I am financially secure (BI2) }\end{array}$ & $\begin{array}{l}\text { (Aeknarajindawat, } 2018 \text {; } \\
\text { Hoffmann et al., 2015; } \\
\text { Trujillo-Barrera et al., 2016) }\end{array}$ \\
\hline
\end{tabular}

Table 1: Scale Development; Source: Authors Compilation

\section{Descriptive Analysis:}

A non-probabilistic snowball sampling method is adopted for the study. Thus, referrals from consumers as chain process responses are collected and about 220 responses are collected in that after eliminating, the inappropriate and semi-filled responses are removed in the final process of data analysis and only a few about three are removed. Finally, 217 samples are considered for analysing the results.

\begin{tabular}{|c|c|c|c|c|}
\hline Demographics & Category & Frequency & Valid Percent & Cumulative Percent \\
\hline \multirow{3}{*}{ Gender } & Male & 131 & 60.4 & 60.4 \\
\hline & Female & 86 & 39.6 & 100 \\
\hline & Total & 217 & 100 & \\
\hline \multirow{5}{*}{ Age } & 25-35 Years & 68 & 31.3 & 31.3 \\
\hline & $36-45$ Years & 77 & 35.5 & 66.8 \\
\hline & 46-55 Years & 49 & 22.6 & 89.4 \\
\hline & Above 55 Years & 23 & 10.6 & 100 \\
\hline & Total & 217 & & \\
\hline \multirow{5}{*}{$\begin{array}{l}\text { Sectorial } \\
\text { Investment }\end{array}$} & Retail Industry & 64 & 29.5 & 29.5 \\
\hline & Pharma Industry & 81 & 37.3 & 66.8 \\
\hline & Energy & 40 & 18.4 & 85.3 \\
\hline & $\begin{array}{l}\text { Information } \\
\text { Technology }\end{array}$ & 32 & 14.7 & 100 \\
\hline & Total & 217 & 100 & \\
\hline \multirow{2}{*}{$\begin{array}{l}\text { Location of } \\
\text { Business }\end{array}$} & Tire I City & 133 & 61.3 & 61.3 \\
\hline & Tire II City & 70 & 32.3 & 93.5 \\
\hline
\end{tabular}




\begin{tabular}{|l|l|l|l|l|}
\multirow{5}{*}{} & Tire II City & 14 & 6.5 & 100 \\
\cline { 2 - 5 } & Total & 217 & 100 & \\
\hline \multirow{4}{*}{$\begin{array}{l}\text { Educational } \\
\text { Qualification }\end{array}$} & SSC/Diploma & 81 & 37.3 & 37.3 \\
\cline { 2 - 5 } & Degree & 126 & 58.1 & 95.4 \\
\cline { 2 - 5 } & Post Graduate & 10 & 4.6 & 100 \\
\cline { 2 - 5 } & Total & 217 & 100 & \\
\hline \multirow{4}{*}{$\begin{array}{l}\text { Work } \\
\text { Experience }\end{array}$} & $0-2$ Years & 77 & 35.5 & 35.5 \\
\cline { 2 - 5 } & $2-5$ Years & 74 & 34.1 & 69.6 \\
\cline { 2 - 5 } & $5-10$ Years & 31 & 14.3 & 83.9 \\
\cline { 2 - 5 } & $>10$ Years & 35 & 4.4 & 100 \\
\cline { 2 - 5 } & Total & 217 & 100 & \\
\hline
\end{tabular}

Analysing the demographic characteristics of the respondents, from the total sample adopted: about 60.4 percent are male and the rest i.e., 39.6 percent are females. When come to age of the respondents about 31.3 percent of the respondents are in 25-35 years, about 35.5 percent of the respondents are in the age of 36-45 years, and about 22.6 percent of the participants are in the age category of 46-55 years. Finally, about 10.6 percent of the respondents are above the age of 55 years. With respect to sectorial investment of the respondents, about 29.5 percent of the respondents prefer to invest in retail sector, and about 37.3 percent of the respondents prefer to invest in pharma industry, and 18.4 percent of the respondents prefer to invest in energy sector and finally, about 14.7 percent of the total respondents prefer to invest in IT sector.

When coming to location of business of the survey respondents, majority of the respondents about 61.3 percent reside in Tire I city and the reset reside in Tire II and Tire III cities. The most important aspect considered for our study is educational qualification of the respondents, about 58.1 possess graduation as qualification who are in majority and only few in number about 4.6 percent are qualified post-graduation. Majority of the respondents possess around two to five years of work experience and their proportion is 69.6 percent on the total sample.

\section{Factor Analysis:}

A principle components factor analysis was performed to determine the factors from the adopted questionnaire. Before to that, KMO and Bartlett's test was performed to determine the sample adequacy and it is found that by test it is 0.629 which is sufficient enough for performing factor analysis (Manideep, 2019c, 2019a). The items of the model are measured on a five point likert scale.

\begin{tabular}{|c|c|c|c|}
\hline \multirow{2}{*}{ Items } & \multicolumn{3}{|c|}{ Component } \\
\cline { 2 - 4 } & Risk Perception & Risk Tolerance & Investment Behaviour \\
\hline RP1 & .904 & & \\
RP2 & .891 & & \\
RP3 & .866 & & \\
RP4 & .842 & .881 & \\
RT1 & & .869 & \\
RT2 & & .795 & \\
RT3 & & & .877 \\
IB1 & & & .876 \\
IB2 & & & \\
\hline
\end{tabular}

Table 2: Rotated Component Matrix

Note: Extraction Method: Principal Component Analysis.

Rotation Method: Varimax with Kaiser Normalization

Rotation converged in 5 iterations.

The constructs and the items are drawn from the literature, but the validity and to examine the variance explained by these constructs to the proposed model a dimension reduction technique is used in the present study. All the items and its responses are loaded in SPSS and Exploratory factor analysis is performed and it is found that four constructs evolved and the variance explained by these constructs is about 77.71 percent. As per the literature, a model explaining 60 percent of variance is considered valid and the factors are decided based on the eigenvalue, if the eigenvalue is $>1$ it is considered as a factor (Manideep, 2019b; Sai Manideep, 2019). The SPSS in table2 displays the result along with Rotation Sums of Squared Loadings. 


\begin{tabular}{|l|c|c|c|c|}
\hline Constructs & Risk Perception & Risk Tolerance & Investment Behaviour & $\boldsymbol{\alpha}$ \\
\cline { 1 - 4 } Risk Perception & 1 & $.202^{* *}$ & -.094 & 0.893 \\
\cline { 1 - 2 } Risk Tolerance & $.202^{* *}$ & 1 & $.182^{* *}$ & 0.820 \\
\cline { 1 - 2 } & -.094 & $.182^{* *}$ & 1 & 0.716 \\
\hline
\end{tabular}

Table 3: Correlation and reliability analysis. Note: $* *$. Correlation is significant at the 0.01 level (2-tailed).

The rotation technique in this model is varimax rotation, which is an non-orthogonal method that, from table2, it can be determined that out of 15 items about 6 items are removed due to cross loadings and item loadings under that factor is less than 0.6. It can be observed from table2, that all the items are $>0.6$ (Correlated with that factor) and 4 items are under Risk Perception, and 3 items are under Risk Tolerance and at last 2 items under Investment Behaviour.

\section{Regression Results and Analysis:}

H1: Risk perception significantly effects the risk tolerance of the investor.

\begin{tabular}{|c|c|c|c|c|c|}
\hline \multirow[b]{2}{*}{ Model } & \multicolumn{2}{|c|}{ Unstandardized Coefficients } & \multirow{2}{*}{\begin{tabular}{|c|} 
Standardized Coefficients \\
Beta
\end{tabular}} & \multirow[b]{2}{*}{$\mathrm{t}$} & \multirow[b]{2}{*}{ Sig. } \\
\hline & $\mathrm{B}$ & Std. Error & & & \\
\hline $\begin{array}{l}\text { (Constant) } \\
\text { Risk Perception }\end{array}$ & $\begin{array}{c}2.755 \\
.180\end{array}$ & $\begin{array}{l}.235 \\
.059\end{array}$ & .202 & $\begin{array}{c}11.704 \\
3.029\end{array}$ & $\begin{array}{l}.000 \\
.003\end{array}$ \\
\hline
\end{tabular}

Table 4: Standardized coefficients risk perception to risk tolerance; Note: Dependent Variable: Risk Tolerance

A simple linear regression method is used to observe the impact of the independent variable risk perception on investors investment behaviour from table4 it can be determined that Risk perception significantly effects the risk tolerance of the investor $(\beta=0.202, \mathrm{P}<0.05)$ the investment behaviour. The overall impact is determined by Coefficient of determinant $\left(\mathrm{R}^{2}=0.036\right)$ i.e. 3 percent.

$\mathrm{H}$ 2: Risk tolerance significantly effects the investment behaviour of the invertor.

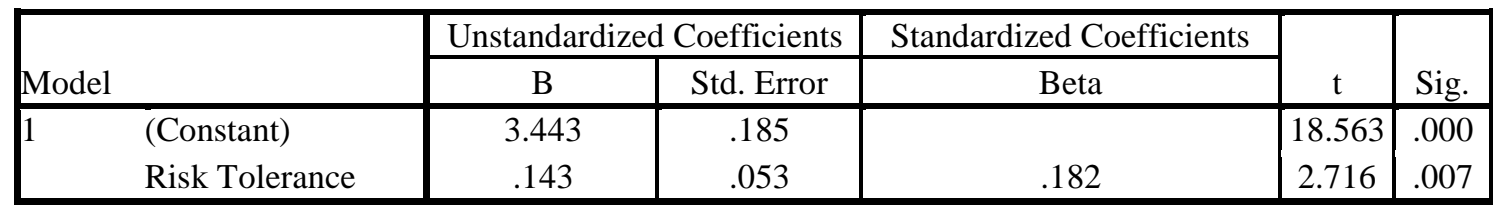

Table 5: Standardized coefficients risk tolerance to investment behaviour; Dependent Variable: Investment Behaviour

A simple linear regression method is used to observe the impact of the independent variable risk tolerance on investors investment behaviour from table 5 it can be determined that Risk tolerance significantly effects the behaviour of the investor $(\beta=0.182, \mathrm{P}<0.05)$ the investment behaviour. The overall impact is determined by Coefficient of determinant $\left(\mathrm{R}^{2}=0.029\right)$ i.e. 3 percent.

H3: Risk perception significantly effects the investment behaviour of the investor.

\begin{tabular}{|cl|c|c|c|c|c|}
\hline \multirow{2}{*}{ Model } & \multicolumn{2}{|c|}{ Unstandardized Coefficients } & Standardized Coefficients & \multirow{2}{*}{ t } & \multirow{2}{*}{ Sig. } \\
\cline { 3 - 6 } & & $\mathrm{B}$ & Std. Error & Beta & 22.354 & .000 \\
& (Constant) & 4.190 & .187 & & -1.390 & .166 \\
\hline
\end{tabular}

Table 6: Standardized coefficients risk perception to investment behaviour; Dependent Variable: Investment Behaviour

A simple linear regression method is used to observe the impact of the independent variable risk perception on investors investment behaviour from table6 it can be determined that Risk perception insignificantly effects the behaviour of the investor $(\beta=-0.094, \mathrm{P}>0.05)$ the investment behaviour.

\section{Conclusion:}

A simple linear regression method is used to observe the impact of the independent variable risk perception on investors investment behaviour from table4 it can be determined that Risk perception significantly effects the risk tolerance of the investor $(\beta=0.202, \mathrm{P}<0.05)$ the investment behaviour. The overall impact is determined by Coefficient of determinant $\left(\mathrm{R}^{2}=0.036\right)$ i.e. 3 percent. A simple linear regression method is used to observe the impact of the independent variable risk tolerance on investors investment behaviour from table5 it can be 
determined that Risk tolerance significantly effects the behaviour of the investor $(\beta=0.182, \mathrm{P}<0.05)$ the investment behaviour. The overall impact is determined by Coefficient of determinant $\left(R^{2}=0.029\right)$ i.e. 3 percent. A simple linear regression method is used to observe the impact of the independent variable risk perception on investors investment behaviour from table6 it can be determined that Risk perception insignificantly effects the behaviour of the investor $(\beta=-0.094, \mathrm{P}>0.05)$ the investment behaviour.

\section{References}

Aeknarajindawat, N. (2018). The influence of risk perception, risk tolerance, overconfidence, and loss aversion towards investment decision making. Journal of Economics, Business, and Accountancy Ventura, 21(3), 401413. https://doi.org/10.9770/JSSI.2020.9.3(7)

Awais, M., Fahad Laber, M., Rasheed, N., \& Khursheed, A. (2016). Impact of financial literacy and investment experience on risk tolerance and investment decisions: Empirical evidence from pakistan. International Journal of Economics and Financial Issues, 6(1), 73-79.

Gibson, R., Michayluk, D., \& Van de Venter, G. (2013). Financial risk tolerance: An analysis of unexplored

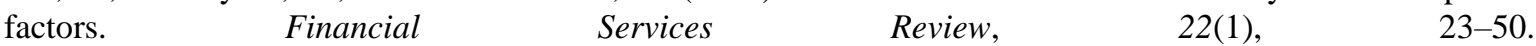
http://search.ebscohost.com/login.aspx?direct=true $\& d b=$ buh $\& A N=87050291 \&$ site=ehostlive\%5Cnhttp://content.ebscohost.com/ContentServer.asp?T=P\&P=AN\&K=87050291\&S=R\&D=buh\&Ebsc oContent=dGJyMNXb4kSep7c4zOX0OLCmr0yep7VSsKe4SbCWxWXS\&ContentCustomer=dGJyMPGnr0 + wqLdRu

Hoffmann, A. O. I., Post, T., \& Pennings, J. M. E. (2015). How Investor Perceptions Drive Actual Trading and Risk-Taking Behavior. Journal of Behavioral Finance, 16(1), 94-103. https://doi.org/10.1080/15427560.2015.1000332

Manideep, A. S. (2019a). Factors Influencing the Adoption of Social Media Marketing in the Wellness Industry: An Empirical Analysis. Journal of Advanced Research in Dynamical and Control Systems, 11(6), 356-362.

Manideep, A. S. (2019b). The Influence of Source Credibility, Endorser Credibility and Message Appeal on Consumers 'Purchase Intention: An Empirical Analysis. International Journal of Recent Technology and Engineering, 8(1), 2845-2850.

Manideep, A. S. (2019c). The strategic implications of worksite wellness programs: A review. Journal of Advanced Research in Dynamical and Control Systems, 11(5), 141-144.

Nobre, H. N., \& Grable, J. E. (2015). The role of risk profiles and risk tolerance in shaping client investment decisions. Journal of Financial Service Professionals, 69(3), 18-22.

Roszkowski, M., \& Davey, G. (2010). Risk perception and risk tolerance changes attributable to the 2008 economic crisis: A subtle but critical difference. Journal of Financial Service Professionals, 64(4), 42-53.

Sai Manideep, A. (2019). Consumers' perception on purchase of wellness products: An empirical analysis. International Journal of Innovative Technology and Exploring Engineering, 8(7).

Trujillo-Barrera, A., Pennings, J. M. E., \& Hofenk, D. (2016). Understanding producers' motives for adopting sustainable practices: The role of expected rewards, risk perception and risk tolerance. European Review of Agricultural Economics, 43(3), 359-382. https://doi.org/10.1093/erae/jbv038

Weber, E. U., \& Milliman, R. A. (1997). Perceived risk attitudes: Relating risk perception to risky choice. Management Science, 43(2), 123-144. https://doi.org/10.1287/mnsc.43.2.123

Weber, E. U., Siebenmorgen, N., \& Weber, M. (2005). Communicating asset risk: How name recognition and the format of historic volatility information affect risk perception and investment decisions. Risk Analysis, 25(3), 597-609. https://doi.org/10.1111/j.1539-6924.2005.00627.x

Zhou, L., \& Dai, Y. (2019). The influencing factors of Haze tolerance in China. International Journal of Environmental Research and Public Health, 16(2). https://doi.org/10.3390/ijerph16020287. 